\title{
Caddo Ceramics from the Middle Caddoan Period Knight's Bluff Site (41CS14), Cass County, Texas
}

Timothy K. Perttula

Heritage Research Center, Stephen F. Austin State University

Follow this and additional works at: https://scholarworks.sfasu.edu/ita

Part of the American Material Culture Commons, Archaeological Anthropology Commons, Environmental Studies Commons, Other American Studies Commons, Other Arts and Humanities Commons, Other History of Art, Architecture, and Archaeology Commons, and the United States History Commons

Tell us how this article helped you.

This Article is brought to you for free and open access by the Center for Regional Heritage Research at SFA ScholarWorks. It has been accepted for inclusion in Index of Texas Archaeology: Open Access Gray Literature from the Lone Star State by an authorized editor of SFA ScholarWorks. For more information, please contact cdsscholarworks@sfasu.edu. 


\section{Caddo Ceramics from the Middle Caddoan Period Knight's Bluff Site (41CS14), Cass County, Texas}

\section{Creative Commons License}

\section{(c) (1) \&}

This work is licensed under a Creative Commons Attribution-NonCommercial 4.0 International License 


\title{
CADDO CERAMICS FROM THE MIDDLE CADDOAN PERIOD KNIGHT'S BLUFF SITE (4ICS14), CASS COUNTY, TEXAS
}

\author{
Timothy K. Perttula
}

\section{Introduction}

During 1997 investigations by the Texas Archeological Research Laboratory associated with the placement of a utility sewer line trench at the Knight's Bluff site (41CS14), and the relocation of the prehistoric midden/cemetery at the site (Jelks 1961:Figure 4), a wide assortment of Caddo ceramics was found. The sample of ceramics includes 651 vessel sherds (in- cluding 240 decorated sherds), three pipe sherds, and five pieces of burned clay. With the exception of nine sherds from the camp sewer line trench area (Perttula et al. 1997), the remainder of the ceramic assemblage is from in and immediately around the midden/cemetery area located near the bluff edge in the western part of the site.

\section{Ceramic Sherds}

For the purposes of more detailed analysis, only those sherds larger than $1 \mathrm{~cm}$ in size were examined for specific information on decorative elements, rim and lip form, surface treatment, temper, and thickness. Sherds surfaces and cross-sections were examined visually and with a $10 \mathrm{X}$ hand lens. The typological assignment of the decorated sherds was based on Jelks (1961) and Suhm and Jelks (1962), while rim and lip forms follow Brown (1996: Figure 2-12). The identification of burnished, polished, and slipped surface treatments follows the criteria specified by Rice (1987:138, 149-150).

\section{Sewer Line Trench Area}

The nine ceramic sherds from this part of the Knight's Bluff site include one plain rim sherd (standing with a flat lip), two body sherds (from the same vessel) with a single unidentified broad-line incised decoration, and six plain body sherds. None of the sherds have been burnished, polished, or slipped. Eight of the sherds have been tempered with grog (crushed fired clay), the other with grog and small pieces of grit (hematite). The one grog-grit tempered body sherd is $8.3 \mathrm{~mm}$ in thickness, while the grog-tempered sherds are slightly thinner, ranging from $5.3 \mathrm{~mm}$ 
(rim) to $7.7 \mathrm{~mm}$ (body). The average vessel wall thickness for the grogtempered sherds from the water line trench area is $6.6 \pm 0.7 \mathrm{~mm}$.

The limited number of sherds, and decorated sherds, from the sewer line trench area prohibits an accurate determination of the assemblage's temporal and cultural affiliations. The frequency of relatively thin grog-tempered ceramics from this part of the site does at least suggest, however, that they were made by Caddoan groups living at the Knight's Bluff site.

\section{Midden/Cemetery Area}

A total of 485 sherds larger than $1 \mathrm{~cm}$ in size were recovered in the shovel test excavations ( $n=17$ shovel tests) in the midden/cemetery area. This includes 283 plain rim, body, and base sherds, and 202 decorated sherds of various sorts. Grog was the preferred temper inclusion in the assemblage, amounting to 61.6 percent of the assemblage, followed by grog-grit (finely crushed hematite; $27.2 \%$ ), grogbone $(6.2 \%)$, and grit $(1.9 \%$; Table 1$)$.

The frequencies of the two main temper classes (grog and grog-grit) is relatively consistent between the plain and decorated sherds, with two exceptions: (1) there is a higher frequency of both grog and grogbone temper in the brushed pottery; and (2) grog-bone temper (the bone and grog inclusions are finely crushed) is more common among several of the engraved sherd types (Table 1).

Sherds with noticeable amounts of bone temper comprise 8.0 percent of the Knight's Bluff site ceramic assemblage. The frequency of bone temper at the site initially seems high considering that Linder-Linsley and Lindsay (1996:39) have suggested that the use of bone temper in East Texas ceramics (and particularly at Wright Patman Lake) is extremely unlikely. It is their opinion that the white aplastic inclusions in Caddoan sherds are not pieces of bone, because any bone in the ceramic paste would have turned black upon firing if it was present at all, given the supposed amount of heat required to turn bone white. This view overlooks the likelihood that the bone was burned or calcined white, then crushed before it was added to the ceramic paste; firing would not destroy the calcined bone temper pieces. Considering that calcined bone is common in the midden deposits at Knight's Bluff, bone being routinely burned as trash in hearths and fires, it would have been a ready source of temper.

There were four plain rims in the assemblage, one each from shovel tests outside the midden (Perttula et al. 1997: Figure 4a, 4d). Each is standing and direct, with no burnishing or polishing, and averaging $4.9 \mathrm{~mm}$ in thickness.

Each of the 11 bases is from a flat disk, ranging from 9.2-13.0 $\mathrm{mm}$ in thickness (mean thickness of $10.6 \pm 0.9 \mathrm{~mm}$ ). The base sherds were recovered from six shovel tests in and outside the midden.

The plain body sherds were from the walls of vessels ranging in thickness from 
Volume 8, Number 4

Table 1. Plain and Decorated Ceramics by Temper Classes from the Midden/ Cemetery Area at the Knight's Bluff Site (41CS14)

\begin{tabular}{|c|c|c|c|c|c|c|c|c|}
\hline Sherd Type & Grog & $\begin{array}{c}\text { Grog- } \\
\text { Grit }\end{array}$ & $\begin{array}{l}\text { Grog- } \\
\text { Grit- } \\
\text { Bone } \\
\end{array}$ & $\begin{array}{l}\text { Grog- } \\
\text { Bone }\end{array}$ & Grit & $\begin{array}{l}\text { Grit- } \\
\text { Bone }\end{array}$ & Bone & Total \\
\hline \multicolumn{9}{|l|}{ Plain Sherds } \\
\hline $\operatorname{Rin}$ & 3 & 1 & - & - & - & - & - & 4 \\
\hline Body & 159 & 83 & 3 & 13 & 5 & 3 & 2 & 268 \\
\hline Base & 7 & 3 & - & $\sim$ & - & - & . & 11 \\
\hline \multicolumn{9}{|l|}{ Decorated Sherds } \\
\hline Parallel Brushed & 43 & 7 & 1 & 9 & 2 & - & - & 62 \\
\hline Diagonal Brushed & 4 & 1 & - & - & - & - & - & 5 \\
\hline Horizontal Brushed & 1 & 1 & - & - & - & - & - & 2 \\
\hline Pease Brushed-Incised & 10 & 5 & - & - & 1 & 1 & - & 17 \\
\hline Nash Neck Banded & 4 & 4 & - & 1 & - & 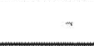 & - & 9 \\
\hline Mckinney Plain & 8 & 3 & - & - & - & - & - & $13 *$ \\
\hline Cass Appliqued & - & 1 & - & - & - & - & - & 1 \\
\hline Diagonal Incised & 5 & 3 & - & - & - & - & - & 8 \\
\hline Parallel Incised & 5 & 4 & - & - & - & - & - & 9 \\
\hline Horizontal Incised & 2 & - & - & - & - & - & - & 2 \\
\hline Herringbone Incised & 1 & - & - & - & - & - & - & 1 \\
\hline Single Líne Incised & 1 & 2 & - & $=$ & - & - & - & 3 \\
\hline Punctated & 3 & - & - & - & - & - & - & 3 \\
\hline Punctated-Incised & 1 & 1 & - & - & - & - & - & 2 \\
\hline Red-Slipped & 3 & 1 & - & - & - & - & - & 4 \\
\hline Barkman Engraved & 9 & 3 & - & 1 & - & - & - & 13 \\
\hline Friendship Engraved & 3 & 1 & - & - & - & - & - & 4 \\
\hline Haley Engraved & 1 & - & - & - & - & - & - & 1 \\
\hline Hatchel Engraved & 1 & - & - & - & - & - & - & 1 \\
\hline Engraved hatched ladder & - & - & - & 1 & - & - & - & 1 \\
\hline Zoned Cross-hatched Engraved & 1 & - & - & 1 & - & - & - & 2 \\
\hline Diagonal Engraved & 1 & - & - & $\therefore$ & - & - & $\approx$ & 1 \\
\hline Horizontal Engraved & 3 & 1 & - & 2 & - & - & - & 8* \\
\hline Horizontal Engraved with hatched triangle & 1 & - & - & - & - & - & - & 1 \\
\hline Single-line Engraved & 13 & 2 & - & - & - & - & - & $16 *$ \\
\hline Double-line Engraved & - & 1 & - & - & - & - & - & 1 \\
\hline Three-line Engraved with pendant & 1 & - & - & - & - & - & - & 1 \\
\hline Parallel Engraved & - & 2 & - & 1 & - & - & - & $4^{*}$ \\
\hline Unidentified Engraved & 4 & 3 & - & - & - & $\therefore$ & - & 7 \\
\hline SUMMARY & 299 & 132 & 4 & 30 & 9 & 4 & 2 & 485 \\
\hline
\end{tabular}

* Temper not determined for all sherds in this class 
5.1-8.2 mm; most of the body sherds were about $6.5-7.0 \mathrm{~mm}$ thick, based on the average thickness of $6.97 \mathrm{~mm}$ for grogtempered sherds; $6.46 \mathrm{~mm}$ for grog-grittempered sherds; and $6.24 \mathrm{~mm}$ for the grog-bone tempered sherds. Some 6.4 percent of the plain body sherds had a burnished exterior and/or interior surface. Several of the sherds also had charred organic remains preserved on their interior surface, indicating they were used in the cooking and heating of foods.

Pease Brushed-Incised and brushed sherds dominate the decorated sherd assemblage from the Knight's Bluff site (Figure 1f-i), between them comprising 42.7 percent of the decorated sherds (Table 1). Most of the brushed sherds are probably from the bodies of Pease Brushed-Incised jars, where the body was commonly decorated with parallel (either vertical or horizontally-oriented) brushed marks (Figure 1f), but also with diagonal brushing. Two rim sherds (one standingdirect and one everted-direct) from jars were also decorated with horizontal brushed marks.

The Pease Brushed-Incised sherds are represented by five rims and 12 body sherds. Four of the rims (mean thickness of $5.5 \pm 0.5 \mathrm{~mm}$ ) are standing, with direct or flat lips, and one is everted and direct. Body wall thickness ranges from 5.1-7.5 $\mathrm{mm}$. Decorations range from: rows of rim punctations with horizontal brushing on the rim (Figure $1 \mathrm{~g}$ ) or vertical brushing on the body; to 3-4 rows of rim punctations; rows of punctations dividing horizontal incised lines on the rim (Suhm and Jelks 1962:Plate 60c, e, g); and verticallyoriented incised lines divided by appliqued ridges. One Pease Brushed-Incised body sherd has partially smoothed over curvilinear incised and brushed marks (Figure 1d), similar to a whole vessel from burial 11 at Knight's Bluff (Jelks 1961: Plate 3a).

The three Nash Neck Banded jar rims are everted and direct $(n=2)$ (Figure 1b) and standing and direct. They average $6.0 \mathrm{~mm}$ in thickness. Body wall thickness ranges from 4.6-9.0 $\mathrm{mm}$. The pronounced neck bands on the larger Nash Neck Banded jars are $14 \mathrm{~cm}$ in width (Figure 1c).

McKinney Plain sherds are represented by vertically-oriented appliqued ridges and rim nodes (Figure 1a) on otherwise plain jars. The single rim is everted and direct, and $6.4 \mathrm{~mm}$ in thickness. Vessel walls are $5.7 \pm 0.4 \mathrm{~mm}$ in thickness.

Only a single Cass Appliqued body sherd was recovered from the Knight's Bluff midden/cemetery area (Figure 1j). It had a series of closely spaced appliqued ridges about $4 \mathrm{~mm}$ in width that ran down the walls of a small jar.

Most of the incised sherds (five rims and 18 body sherds) were small and the overall character of the decorative elements is unclear, but parallel, horizontal, and diagonal decorations were discerned in the assemblage (Table 1). One diagonal incised body sherd (Figure 1e) is comparable to what Jelks (1961:Plate 8h-i) 
Figure 1. Decorated Sherds and Pipe Sherds from the Midden/Cemetery Area at the Knight's Bluff Site:

top row, left to right, a) McKinney Plain (ST 22, 20-40 cm), b-c) Nash Neck Banded (ST 34, 40-60 cm and ST 22, 20-40 cm); second row, left to right, d) smoothed over curvilinear incised (ST 24, 20-40 cm), e) diagonal incised (ST 22, 20-40 cm); f) Pease Brushed-Incised (ST22, 20-40 cm); third row, left to right, g-i) Pease Brushed-Incised (ST 33, 40-60 cm; ST $35,20-40 \mathrm{~cm}$, and ST 34, 0-20 cm); fourth row, left to right, j) Cass Appliqued (ST 36, 0-20 $\mathrm{cm}$ ), k) Friendship Engraved (Incised) (ST 38, 20-40 cm), 1) horizontal engraved (ST 33, 20 $40 \mathrm{~cm}$ ); bottom row, left to right, $\mathrm{m}$ ) horizontal engraved with hatched triangle (ST 24, 40-60 $\mathrm{cm}), \mathrm{n})$ possible Haley Engraved bottle sherd (ST 22, 20-40 cm), o-p) Friendship Engraved (ST 33, 0-20 cm and ST 35, 20-40 cm), q) pipe stem (ST 36, 0-20 cm), r) pipe bowl (ST 33, $40-60 \mathrm{~cm})$

defined as the late variant of Dunkin Incised at the Knight's Bluff site. Another, with a herringbone incised decorative element, could represent either another late Dunkin Incised sherd or an example of Pease Brushed-Incised (Suhm and Jelks 1962:Plate 60I), although the small sherd lacks the characteristic body panel. The incised rim sherds are standing and direct, with a mean thickness of $5.5 \pm 0.6 \mathrm{~mm}$. Body wall thickness ranges from 5.3-9.4 $\mathrm{mm}$, with a mean of $6.6 \pm 1.1 \mathrm{~mm}$.

The two incised-punctated sherds include one with large cane punctations within an incised zone. It may be from either a Crockett Curvilinear Incised or Pennington Punctated-Incised bowl. Both ceramic types occur in very small amounts at Knight's Bluff (Jelks 1961:35): 20 sherds out of a total sample of 3031 decorated sherds.

The three small punctated sherds (all grog-tempered) had circular, fingernail, and tool impressions. The sherd with small circular punctations had a red-slip on interior and exterior surfaces.

Four of the decorated sherds simply have a thin burnished or polished red clay slip on interior and/or exterior surfaces; whether they are from plain red-slipped vessels is unknown because they are body sherds. They are from relatively thin (mean thickness of $5.6 \pm 0.3 \mathrm{~mm}$ ) bowls or carinated bowls tempered with grog or grog-grit.

Barkman Engraved is the most common engraved type in the Knight's Bluff midden and cemetery area (Table 1). The type is represented by 13 body sherds (mean thickness of $5.2 \pm 0.6 \mathrm{~mm}$ ) with the characteristic rectilinear engraved designs filled with hatched or cross-hatched marks, short dashes or dashed lines, or punctations (Suhm and Jelks 1962:Plate $4 c^{\prime}, m$ for decorative elements on Barkman Engraved vessels represented by examples from the Knight's Bluff midden/ cemetery assemblage). Two of the sherds 
Volume 8, Number 4

have white or red pigments within the engraved lines.

Other identified engraved types include four sherds of Friendship Engraved (Figure 1o-p) with cross-hatched bands, semicircles, and negative scrolls, one Haley Engraved bottle sherd (Figure 6n; Suhm and Jelks 1962:Plate 31e), and one Hatchel Engraved bottle sherd. The latter had portions of a vertically-oriented hatched zone (Suhm and Jelks 1962:Plate 34b). On one sherd of a Friendship Engraved carinated bowl, the decorative element is executed with incised lines rather than engraved (Figure 1k). A similar vessel was recovered from Burial 7 at Knight's Bluff (1961:Plate 2b). The single Friendship Engraved rim is standing and rolled with a horizontal hatched zone below the lip, and a vertically-oriented hatched divider on the rim (Figure 1p; Suhm and Jelks 1962:Plate 23a).

Because of their small size, the decorative elements for 42 other engraved sherds -- all from bowls or carinated bowls -- could not be fully discerned. Instead, they were categorized by the apparent design, such as the number and orientation of the engraved lines, or other partial elements (Table 1). By far the most common decorations were one to three engraved lines, either clearly horizontally placed on the rim $(n=9$; Figure 11$)$, or labeled single, double, or parallel engraved if they occurred on body sherds where the orientation of the engraved lines could not be determined. The rims are standing and direct $(\mathrm{n}=5)$, standing and rolled $(\mathrm{n}=2)$, and standing and flat $(\mathrm{n}=1)$. Two other body sherds with horizontal engraved lines have either associated hatched triangles (Figure $1 \mathrm{~m}$ ), or a small engraved element pendant from the lowermost horizontal line.

It is likely that most of these sherds are from Barkman Engraved vessels, which have several horizontal lines at the top of the bowl rim, with narrow rectilinear engraved bands or zones below (Suhm and Jelks 1962:Plate 4). Two of these engraved sherds have red pigment smeared in the engraved lines, also characteristic of the Barkman Engraved ceramics from the Knight's Bluff site.

The remainder of the engraved sherds have small portions of hatched bands, ladders, or zones $(n=3)$, diagonal engraved lines $(n=1)$, or unidentifiable elements $(n=7)$. The sherd with an engraved hatched ladder also has an exterior red slip.

\section{Pipe Sherds}

The three long-stemmed Red River style (Hoffman 1967) pipe sherds (one stem and two bowl sherds) were found in two shovel tests in and immediately adjacent to the midden. The stem section (Figure 1q) had an exterior stem diameter of 9.2 $\mathrm{mm}$ and a $4.4 \mathrm{~mm}$ interior stem diameter, and may be from a Haley variety of the Red River style pipe. It is tempered with finely crushed grog. The bowl sherds were between 2 and $4.1 \mathrm{~mm}$ thick, and tempered with either finely crushed grog 
or bone. The one rim is standing and direct (Figure 1r).

\section{Burned Clay}

Only five pieces of burned clay were recovered in the midden/cemetery area.
Each of the pieces has been highly oxidized, and they are bright red in color, with irregular shapes and sizes (ranging from $8-18 \mathrm{~mm}$ in length and $7-13 \mathrm{~mm}$ in length); none of the burned clay pieces have impressions. The burned clay pieces may be from the lining of clay hearths or the accidental firing of wads of clay.

\section{Summary of Midden/Cemetery Area Ceramics}

The ceramics recently recovered in the Midden/Cemetery area at the Knight's Bluff site are consistent with the assemblage previously documented by Jelks (1961) from the site. Our assemblage is dominated by brushed sherds (probably from Pease Brushed-Incised jars), Pease Brushed-Incised, McKinney Plain, Barkman Engraved, Nash Neck Banded, and a small assortment of incised (some the late variant of Dunkin Incised) and engraved sherds (Table 1). Brushed sherds comprise 43 percent of the decorated sherds, followed by engraved (30\%), incised (11\%), appliqued (7\%), neck banded (4\%), and punctated/punctated-incised ( $2 \%$ ).

The sherd assemblage recovered by Jelks (1961:34-35) is also dominated by brushed sherds ( $\mathrm{n}=594)$, Pease Brushed-Incised $(n=392$ sherds and five vessels), Barkman Engraved $(n=336)$, McKinney Plain $(n=$ 219), and Nash Neck Banded ( $\mathrm{n}=142$ sherds and three vessels), along with the late variant of Dunkin Incised $(n=86)$. Brushed sherds amount to 33 percent of the 3031 decorated sherds in Jelks' sample, somewhat lower than in our sample, then followed by engraved sherds (32\%), incised $(14 \%)$, punctated/punctatedincised $(6.8 \%)$, neck banded (4.7\%), and appliqued (3.5\%) sherds. Cliff (1997: Table 1) places the majority of the Caddoan ceramics from Jelks' work in a late phase (eastern facet) of the Middle Caddoan period, dating ca. A.D. 1300-1400.

The only differences between the two samples is in the relative frequencies of brushed (43 vs. 33 percent) and punctated/ punctated-incised sherds ( 2 vs. 6.8 percent). These differences probably relate to the fact that the Knight's Bluff site also has a small Early Caddoan component on it (with no brushed pottery and higher frequencies of incised and punctated ceramics), which was sampled to some extent by Jelks' extensive excavations across much of the bluff in addition to his work in the midden/cemetery area, whereas our work focused intensively on the late Middle Caddoan period midden/cemetery area where the ceramic assemblage is dominated by brushed and engraved pottery of the types Pease Brushed-Incised and Barkman Engraved. 
Volume 8, Number 4

\section{References Cited}

Brown, J. A.

1996 The Spiro Ceremonial Center: The Archaeology of Arkansas Valley Caddoan Culture in Eastern Oklahoma. 2 Vols. Memoirs No. 29. Museum of Anthropology, University of Michigan, Ann Arbor.

Cliff, M. B.

1997 The Middle Caddoan Period in the Lower Sulphur River Area. Journal of Northeast Texas Archaeology 9:9-16.

Hoffman, M. P.

1967 Ceramic Pipe Chronology along the Red River Drainage in Southwestern Arkansas. The Arkansas Archeologist 8(1):4-14.

Jelks, E. B.

1961 Excavations at Texarkana Reservoir, Sulphur River, Texas. River Basin Survey Papers 21. Bulletin 179, Bureau of American Ethnology, Smithsonian Institution, Washington, D.C.

Linder-Linsley, S. E. and L. D. Lindsay 1996 Cultural Resources Survey 1996:
Wright Patman Lake and Lake O' the Pines, Bowie, Cass, and Marion Counties, Texas. Review Draft. LL Consultants, Dallas.

Perttula, T.K., D. J. Prikryl, and B. Nelson 1997 Archeological Evaluation of a Proposed Sewer Line in the Knight's Bluff Campground at Atlanta State Park, and Delineation of the Knight's Bluff Site (4ICSI4) Cemetery/Midden Areas. Final report submitted to Texas Parks and Wildlife Department by the Texas Archeological Research Laboratory, The University of Texas at Austin.

Rice, P. M.

1987 Pottery Analysis: A Sourcebook. University of Chicago Press, Chicago.

Suhm, D. A. and E. B. Jelks

1962 Handbook of Texas Archeology: Type Descriptions. Special Publication No. 1, Texas Archeological Society, and Bulletin No. 4, Texas Memorial Museum, Austin. 